\title{
Dual symbiosis in the cold-seep thyasirid clam Maorithyas hadalis from the hadal zone in the Japan Trench, western Pacific
}

\author{
Yoshihiro Fujiwara ${ }^{1, *}$, Chiaki Kato ${ }^{2}$, Noriaki Masui $^{2}$, Katsunori Fujikura $^{1}$, \\ Shigeaki Kojima ${ }^{3}$
}

\author{
${ }^{1}$ Marine Ecosystems Research Department, and ${ }^{2}$ Frontier Research Program for Deep-Sea Environment, \\ Japan Marine Science and Technology Center (JAMSTEC), 2-15 Natsushima, Yokosuka, Kanagawa 237-0061, Japan \\ ${ }^{3}$ Ocean Research Institute, University of Tokyo, 1-15-1 Minamidai, Nakano, Tokyo 164-8639, Japan
}

\begin{abstract}
The bacterial endosymbionts of the thyasirid clam Maorithyas hadalis collected from the hadal zone in the Japan Trench were characterized. Two distinct phylotypes of endosymbiotic bacteria were discovered within the gill tissues by molecular phylogenetic analysis and in situ hybridization. Symbiont Type I was affiliated with thioautotrophic symbionts of vesicomyid clams and deep-sea mussels from deep-sea hydrothermal vents and cold seeps. Symbiont Type II was not related to previously reported bacterial symbionts, and was distantly related to the free-living chemoautotrophic bacteria (genera Thiomicrospira and Hydrogenovibrio). In situ hybridization experiments indicated spatial partitioning between the $2 \mathrm{M}$. hadalis symbionts, with Symbiont I occurring mainly in the outer regions of bacteriocyte zones and Symbiont II situated predominantly within inner regions of bacteriocyte zones. This is the deepest chemosynthetic symbiosis ever recorded and the first report to show spatial partitioning between the intracellular endosymbionts in marine invertebrates.
\end{abstract}

KEY WORDS: Dual symbiosis · Spatial partitioning - Thyasirid clam · Chemosynthetic community Hadal zone $\cdot$ Japan Trench $\cdot$ In situ hybridization · Phylogenetic analysis

\section{INTRODUCTION}

Thyasirid clams are endobenthic bivalves that live in fine sediments and are found predominantly in boreal coastal seas (Kauffman 1967). The clams have thick gills, reduced palps, a short simple gut and an elongated burrowing foot (Allen 1958). Several species are known to harbor symbiotic bacteria in their gills (Southward 1986). Unlike most chemosynthetic endosymbioses in which the bacteria are intracellular, the symbionts of thyasirids have been reported to occur extracellularly (Southward 1986), although the style of symbiosis in thyasirid clams is disputed (Fujikura et al.

\footnotetext{
*E-mail: fujiwara@jamstec.go.jp
}

1999). Fisher (1990) suggested that the symbioses in thyasirid clams might represent the more primitive condition, as opposed to the highly integrated, intracellular associations between bacterial symbionts and other bivalves such as vesicomyid clams and deep-sea mussels.

In 1998, a dense aggregation of the thyasirid clam Maorithyas hadalis was discovered at a depth of $7326 \mathrm{~m}$ in the Japan Trench using the ROV 'Kaiko' (Fujikura et al. 1999, Okutani et al. 1999). Transmission electron microscopic (TEM) observations revealed the existence of numerous bacteria-like particles in the gill tissue, and several other lines of supporting evidence strongly suggested that the particles were symbiotic bacteria and that the clam relied on chemosynthesis of 
the symbionts for their nutrition (see Fujikura et al. 1999). Unlike other symbiont-harboring thyasirids, the symbionts of $M$. hadalis were reported to occur intracellularly (Fujikura et al. 1999), although it was not entirely conclusive because the micrographs showed no host cell organelles with the symbionts within single cells.

The phylogeny of bacterial symbionts from many host taxa has been examined using 16S ribosomal RNA gene (16S rDNA) sequence analysis (Distel et al. 1988, 1994, 1995, Eisen et al. 1992, Cary 1994, Distel \& Cavanaugh 1994, Dubilier et al. 1995, 1999, Durand \& Gros 1996, Durand et al. 1996, Feldman et al. 1997, Peek et al. 1998, Di Meo et al. 2000, Fujiwara et al. 2000). However, such analysis for thyasirids has been limited to Thyasira flexuosa (Distel \& Wood 1992), which had thioautotrophic symbionts phylogenetically related to those of lucinid clams and vestimentiferan tubeworms (Distel \& Wood 1992).

The goal of this investigation was to clarify the symbiotic form (intra- or extracellular) in Maorithyas hadalis using TEM, and to characterize the symbionts using 16S rDNA sequence analysis. Unexpectedly, our results showed 2 distinct types of symbionts located in the gill tissue of the clam.

\section{MATERIALS AND METHODS}

Specimen collection. Maorithyas hadalis specimens were collected from the Japan Trench during Dives 110 (7336 m depth) and 112 (7434 $\mathrm{m}$ depth) of the ROV 'Kaiko' in 1999. Upon recovery, the clams were immediately transferred to fresh, chilled $\left(\sim 4^{\circ} \mathrm{C}\right)$ seawater.

Treatment for TEM observations. Small pieces of gill tissue from 3 specimens were prefixed with $0.2 \%$ glutaraldehyde in seawater for $1 \mathrm{~h}$ at $4^{\circ} \mathrm{C}$. Prefixed gills were dissected into 2 to $3 \mathrm{~mm}$ blocks using razor blades. Blocks were rinsed 10 times with $0.05 \mathrm{M}$ phosphate buffer ( $\mathrm{pH}$ 7.8) for $10 \mathrm{~min}$ at room temperature, and additional fixation was performed for $3 \mathrm{~h}$ with $2.5 \%$ glutaraldehyde in $0.2 \mathrm{M}$ phosphate buffer containing $4 \%$ tannic acid ( $\mathrm{pH} \mathrm{6.8)} \mathrm{at} \mathrm{room} \mathrm{temperature.}$ Blocks were again rinsed 10 times with $0.05 \mathrm{M}$ phosphate buffer ( $\mathrm{pH}$ 7.8) for $10 \mathrm{~min}$ at room temperature and were stored in $0.05 \mathrm{M}$ phosphate buffer $(\mathrm{pH} 7.8$ ) containing $10 \mathrm{mM}$ sodium azide for about $3 \mathrm{wk}$ at $4{ }^{\circ} \mathrm{C}$. Post-fixation was conducted for $2 \mathrm{~h}$ in $1 \% \mathrm{OsO}_{4}$ in $0.05 \mathrm{M}$ phosphate buffer $(\mathrm{pH} 7.8)$ at $4^{\circ} \mathrm{C}$. Tissues were dehydrated and embedded in EPON 812 resin (TAAB). Ultra-thin sections of the specimens were stained with aqueous uranyl acetate and lead citrate, and were observed by a JEOL JEM-1210 TEM at an acceleration voltage of $80 \mathrm{kV}$.
DNA preparation. DNA was extracted from the gill tissue of 3 specimens of the host species. To eliminate surface contaminants, each gill was thoroughly washed in autoclaved and filtered $(0.22 \mu \mathrm{m})$ seawater. DNA extraction from tissue samples followed physical disruption in liquid nitrogen and chemical lysis as described by Takai \& Sako (1999).

Polymerase chain reaction (PCR) amplification. Bacterial 16S rDNA was amplified by PCR using the Ex Taq PCR kit (TaKaRa, Kyoto). Two oligonucleotide primers $(1 \mu \mathrm{M}$ each) and $<1 \mu \mathrm{g}$ of DNA template were added to the reaction mixtures. Thermal cycling was as follows: denatured at $96^{\circ} \mathrm{C}$ for $20 \mathrm{~s}$, annealed at $55^{\circ} \mathrm{C}$ for $45 \mathrm{~s}$, and extended at $72^{\circ} \mathrm{C}$ for $2 \mathrm{~min}$ for a total of 35 cycles. The oligonucleotide primer sequences used for bacterial 16S rDNA amplification were Bac27F and 1492R. Molecular size of the PCR products was checked by $1.2 \%$ Agarose S (Nippon Gene, Toyama) gel electrophoresis.

Cloning of amplified 16S rDNAs. Amplified 16S rDNAs were extracted from the agarose gel slices sequentially with phenol, phenol/chloroform/isoamyl alcohol and chloroform/isoamyl alcohol, and precipitated with ethanol (Takai \& Sako 1999). After centrifugation, DNA pellets were resuspended in sterile distilled water. The purified $16 \mathrm{~S}$ rDNAs were cloned into the pCR-TOPO vector using the TOPO TA cloning kit (Invitrogen, San Diego).

Restriction fragment length polymorphism (RFLP) analysis of inserts. Each white colony was directly used as a template for the PCR amplification using the Insert Check-Ready-Blue kit (Toyobo, Osaka). The PCR products containing appropriately sized inserts were identified by $1.2 \%(\mathrm{w} / \mathrm{v})$ agarose gel electrophoresis. The appropriately sized inserts were used as a template for PCR amplification using Bac27F and $1492 \mathrm{R}$ and the PCR products were subjected to RFLP analysis using restriction enzymes that recognize a 4 bp restriction site. Two such restriction enzymes were used, MspI (C'CGG) and RsaI (GT'AC). The restriction enzyme reaction products were electrophoresed through a $3 \%$ Agarose X (Nippon Gene) gel.

Sequencing of amplified 16S rDNAs. DNA sequencing of the amplified 16S rDNA clones was performed using the BigDye Terminator Cycling Sequencing Ready Reaction Kit (PE Applied Biosystems, Foster City, CA, USA). Nine universal 16S rDNA-specific primers were used in sequencing reactions (Kato et al. 1997). Sequencing was performed using the ABI PRISM 310 genetic analyzer. The sequences reported here have been deposited in the DDBJ database under Accession Nos. AB042413 and AB042414.

Sequence and phylogenetic analyses. Nearly complete sequences of the $16 \mathrm{~S}$ rDNAs were analyzed using the gapped-BLAST search algorithm (Altschul et 
al. 1997, Benson et al. 2000) to estimate the degree of similarity to other $16 \mathrm{~S}$ rDNA sequences. Sequences of approximately $1500 \mathrm{bp}$ were used to run the similarity analysis. The database used for similarity analyses was the non-redundant nucleotide sequence database from GenBank. Sequences were manually aligned and phylogenetic analyses were restricted to nucleotide positions that were unambiguously alignable in all sequences. Calculation of the distance matrix and neighbor-joining (NJ) analysis were accomplished using the CLUSTAL X software package (Thompson et al. 1997). Maximum likelihood (ML) and maximum parsimony (MP) analyses were also performed using the PHYLIP package, Version 3.572 (obtained from J. Felsenstein, University of Washington, Seattle). Bootstrap analyses were used to provide confidence estimates for phylogenetic tree topologies in NJ and MP analyses.

In situ hybridization. Two ribosomal RNA-targeted oligonucleotide probes were designed for detection of 2 types of bacteria that were potentially predominant in the gill tissue of Maorithyas hadalis. Probe I (5'TCGCCACTAAGAGGTAAATCCT-3') was designed for detection of bacterial 16S rDNA of 'Symbiont I'. Probe II (5'-TCGACACTAAAATCTCTAAGGAT-3') was designed for detection of bacterial 16S rDNA of 'Symbiont II'. Both probes corresponded to Positions 839 to 859 in Escherichia coli 16S rDNA. EUB338 (Amann et al. 1990) was also used to label members of the domain Bacteria as a positive control. The sequences of Probes I and II were analyzed using the gappedBLAST search algorithm (Altschul et al. 1997, Benson et al. 2000) to examine whether any other sequences had similarity to these probe sequences. In addition, dot-hybridization analysis was conducted with bacterial 16S rDNA to check the specificity of the probes. The amplified 16S rDNAs, used for RFLP analysis, were blotted onto positively charged nylon membrane, Hybond-N+ (Amersham Pharmacia Biotech, Little Chalfont, UK). The membranes hybridized with Probe I, Probe II, or EUB338, which were labeled at the 5 '-end with digoxigenin (DIG) and purified by HPLC (Amersham Pharmacia Biotech). After hybridization, the membranes were washed, and the DIG-labeled oligonucleotide probes hybridized with the targeted $16 \mathrm{~S}$ rDNA sequences were detected using the antiDIG-AP fab fragments, NBT and BCIP (Boehringer Mannheim, Indianapolis, USA) according to the procedure recommended by the manufacturer. The hybridization was conducted for $12 \mathrm{~h}$ at $43^{\circ} \mathrm{C}$ for Probe I, at $48^{\circ} \mathrm{C}$ for Probe II, and at $55^{\circ} \mathrm{C}$ for EUB338 (each probe $=5$ pmol ml-1).

For in situ hybridization, gill tissues were taken from 2 specimens of live clams and fixed in Bouin's solution for $22 \mathrm{~h}$. The tissues were dehydrated with normal butyl alcohol, embedded in paraffin and sectioned in $3 \mu \mathrm{m}$ thick strips according to standard procedures. The hybridization was conducted on the sequential sections using 4 different probes: Probe I, Probe II, EUB338, and the RNA negative control DIG oligo probe (Kreatech Diagnostics, Amsterdam). The universal RISH and detection kit (Kreatech Diagnostics) was used for the experiments for $12 \mathrm{~h}$ at the same temperature as mentioned above for each

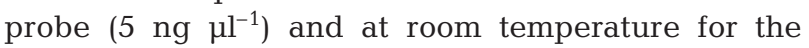
negative control probe. Another hybridization experiment was performed on muscle tissue from the clam as a negative control using the 4 probes mentioned above.

\section{RESULTS}

\section{Microscopic observations}

Unlike other thyasirid and lucinid clams whose gill filaments are ciliated on the outer surface, gill filaments of Maorithyas hadalis were divided into primarily 2 regions: the outermost zones (with no cilia) and bacteriocyte zones (see Fig. 4D). Numerous bacteria were observed in the epithelial cells in the bacteriocyte zones using TEM and a light microscope (Fig. 1A, see also Fig. 4D). The bacteria were contained in vacuoles within the host cells, unlike other thyasirid symbioses, and most were localized in the apical region of the cells just below the surface (Fig. 1A,B). The bacteria were small cocci or short rods that averaged $1.46 \mu \mathrm{m}$ (SD = $0.28, \mathrm{n}=22$ ) along the major axis, with trilamellar cell envelopes typical of gram-negative bacteria, and they did not contain membranes or other distinctive structures in their cytoplasm (Fig. 1B,C). No morphological polymorphism was observed in the bacteria except in external form (i.e. cocci or short rods). Divisional stages of the bacteria were observed (Fig. 1C). Secondary lysosomes containing the intermediate stages of bacterial digestion were also observed, concentrated near the basal portion of the host epithelial cells (Fig. 1A,D). Although rare, symbiont vacuoles at the apical region of the bacteriocytes were observed with open connections to the exterior (Fig. 1A,E).

\section{RFLP analysis}

RFLP analysis was performed on 46 appropriately sized inserts that were amplified from 3 specimens of Maorithyas hadalis using Bac27F and 1492R as primers. Two distinct patterns, named Pattern I and Pattern II, appeared. The ratios of Patterns I and II for the 3 specimens were 11:8, 8:4, and 6:9 (total $=25: 21)$. 


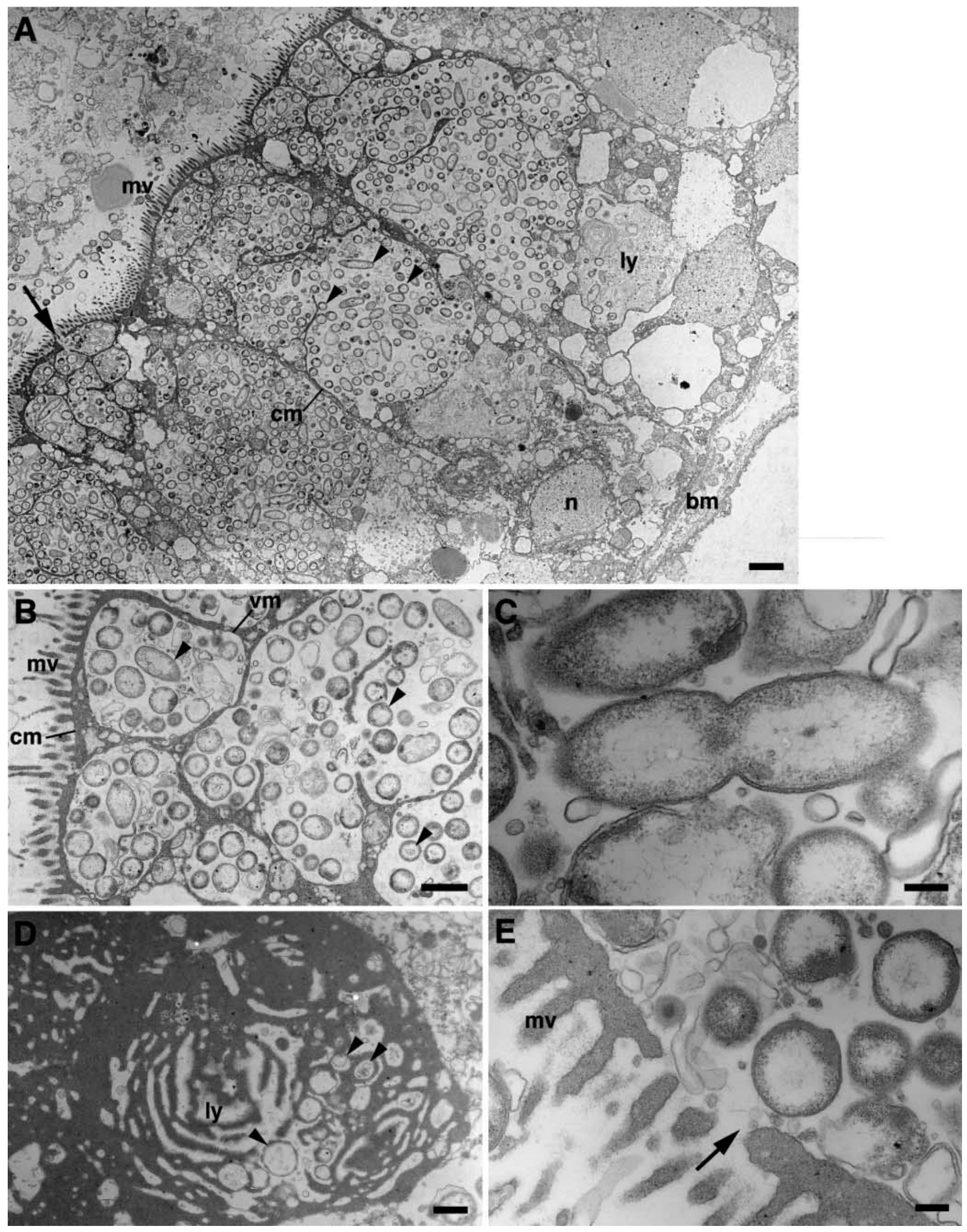


Fig. 1. Maorithyas hadalis. Transmission electron micrographs of a transverse section of gill filaments. (A) Intracellular gramnegative bacterial symbionts (arrowheads) contained in vacuoles within the host bacteriocytes that occurred in a bacteriocyte zone; an arrow indicates a vacuole opening towards the exterior; bm: basal membrane; cm: cytoplasmic membrane; ly: lysosome mv: microvilli; n: nucleus (scale bar $=2 \mu \mathrm{m}$ ). (B) Intracellular gram-negative bacterial symbionts (arrowheads) without stacked internal membranes; vacuolar membrane and the cytoplasmic membrane of host bacteriocyte are visible between the symbionts and the external environment; $\mathrm{cm}$ : cytoplasmic membrane; mv: microvilli; vm: vacuolar membrane (scale bar $=1 \mu \mathrm{m})$. (C) Divisional stage of an intracellular gram-negative bacterial symbiont (scale bar $=200 \mathrm{~nm}$ ). (D) Digestion of bacterial symbionts (arrowheads) in secondary lysosome (ly) near the basal portion of a bacteriocyte (scale bar = 500 nm). (E) Open connection (arrow) of symbiont vacuoles at the outermost region of the bacteriocytes to the exterior; mv: microvilli $(\mathrm{scale}$ bar $=200 \mathrm{~nm}$ )

\section{S rDNA gene sequences}

Partial sequences ( 500 bp) of bacterial 16S rDNA from each RFLP pattern from 3 specimens were determined. The sequences of Patterns I and II differed (<90\% homology), and further comparison within each RFLP pattern showed that members shared nearly identical sequences (a total of 4 inserts of Pattern I and 5 inserts of Pattern II were checked). Nearly complete sequences of 16S rDNA from Pattern I and Pattern II inserts were determined. The lengths of the Pattern I and Pattern II inserts were 1467 and $1464 \mathrm{bp}$, respectively.

\section{Phylogenetic analyses of 16S rDNA sequences}

Phylogenetic analyses performed by neighbor-joining (NJ), maximum parsimony (MP) and maximum likelihood (ML) methods placed the sequences of Pattern I (called Symbiont I) and Pattern II (called Symbiont II) within the $\gamma$ subdivision of Proteobacteria containing the thioautotrophic and methanotrophic symbionts associated with marine invertebrate hosts (Fig. 2). These 2 sequences were unique to the host thyasirid and differed from those of symbionts from other host species or of free-living bacteria.

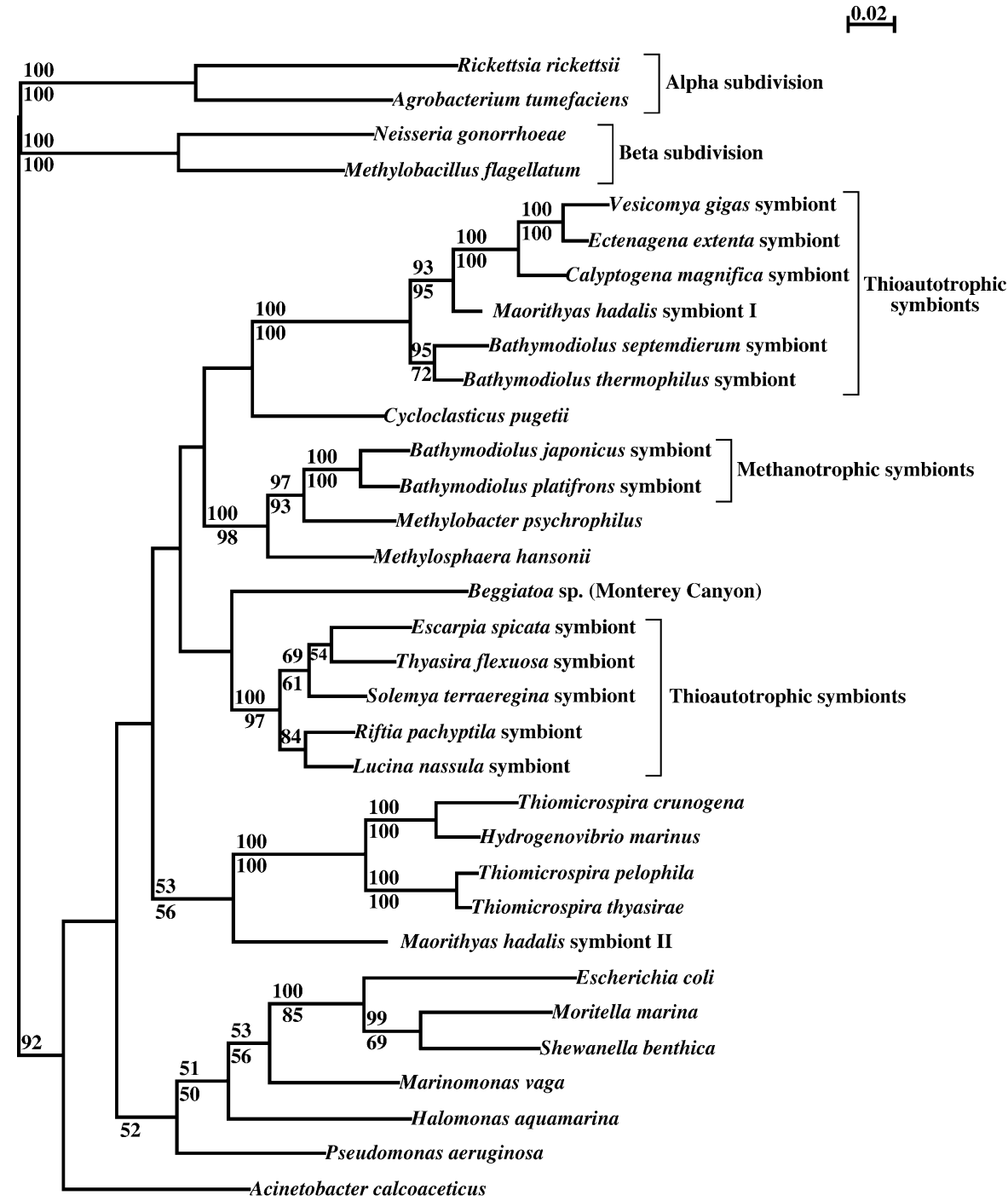

Fig. 2. Phylogenetic placement of bacterial symbionts from Maorithyas hadalis based on 16S rRNA gene sequences. Maximum likelihood tree of members of the $\gamma$-Proteobacteria with the $\alpha$ - and $\beta$-Proteobacteria as an outgroup are shown. Scale bar represents 0.02 nucleotide substitutions per sequence position. Percentage of 1000 bootstrap resamplings is indicated. Bootstrap values greater than $50 \%$ are shown, with upper and lower values representing those from neighbor-joining and maximum parsimony methods, respectively. Symbionts of the clam examined in this study are highlighted (in frames). Accession numbers used for this study were as follows: AB008796, AB036709, AB036710, AB036711, AF016046, AF035721, AF035725, AF035726, AF064543, AF064545, AF152597, AF159045, AF165909, AF199439, AF237678, AJ297540, D12784, D86374, E05133, L01575, L40809, M21293, M34130, M95651, M99445, U12624, U62131, U67929, U77478, X67025, X95229 
In all 3 phylogenetic analyses, the Symbiont I sequence consistently fell into a clade with thioautotrophic symbionts of vesicomyid clams and deep-sea mussels. Bootstrap values of $100 \%$ in NJ and MP analyses demonstrate that the clade is monophyletic. The Symbiont II sequence formed an isolated branch and was not closely related to other symbiotic or free-living bacteria in the $\gamma$ subdivision of Proteobacteria. The free-living bacterial genera Thiomicrospira and Hydrogenovibrio were consistently placed on the neighboring branches of the Symbiont II sequence in all 3 treeing methods, but bootstrap analyses did not support a close relationship.

\section{In situ hybridization}

The similarity analysis using the gapped-BLAST search algorithm showed that no sequence had similarity to Probe II, but that the homologous position of the 16S rDNA sequences of Bathymodiolus thermophilus and B. puteoserpentis thioautotrophic symbionts were identical to Probe I. To check the specificity of the 2 probes (Probes I and II) for in situ hybridization experiments, dot-hybridization analysis was conducted with the PCR products of 16S rDNA from Symbionts I and II (Fig. 3). Probe I strongly hybridized with Symbiont I and not with Symbiont II. Probe II strongly hybridized with Symbiont II and weakly hybridized with Symbiont I. A positive control probe, EUB338, strongly hybridized with both $16 \mathrm{~S}$ rDNAs.

In situ hybridization was conducted on the sequential sections of gill or muscle tissue of Maorithyas hadalis using 4 different probes (Probe I, Probe II, EUB338, and the RNA negative control DIG oligo probe). Probe I, Probe II and EUB338 hybridized with sections of gill tissue (Fig. 4A-C) and not with sections

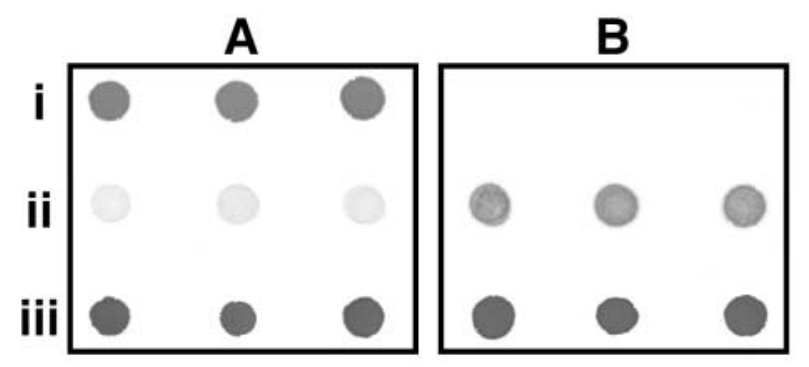

Fig. 3. Dot-hybridization analysis for checking the probespecificity. Hybridization of (i) the Symbiont I-specific probe (Probe I), (ii) the Symbiont II-specific probe (Probe II) and (iii) the universal eubacterial probe (EUB338) labeled with digoxigenin (DIG) was conducted with the amplified 16S rDNA of (A) Pattern I and (B) Pattern II from gill tissue of Maorithyas hadalis using Bac27F and 1492R primers. A total of $30 \mathrm{ng}$ of the 16S rDNA was blotted as each dot on the membrane of muscle tissue (data not shown). The negative control probe did not hybridize with sections of either tissue (data not shown). The hybridization reactions of Probes I and II were localized within the epithelial cells only in the bacteriocyte zones. The hybridization patterns of the 2 probes were different (Fig. 4A,B). The hybridization reaction of Probe I was concentrated in the bacteriocyte zones closer to the outermost zones (Fig. 4A). The intensity of the reaction gradually decreased towards the proximal region until it disappeared. The hybridization reaction of Probe II was concentrated in the bacteriocyte zones nearer the center (far from the surface) of the gill tissue (Fig. 4B). The hybridization reaction of EUB338 was seen in most epithelial cells in the bacteriocyte zones (Fig. 4C).

\section{DISCUSSION}

TEM observations confirmed that the symbiosis in Maorithyas hadalis was intracellular, unlike the extracellular symbiosis in other thyasirid clams. Southward (1986) reported that the symbionts in thyasirid clams appeared to be extracellular based on TEM observations. The bacteria occurred between a thin cuticle and the apical membrane of the host cell. However, Fujikura et al. (1999) suggested that the symbionts of M. hadalis were intracellular based on their TEM observations. In our TEM micrographs, the vacuolar membrane and the cytoplasmic membrane of host bacteriocytes are clearly visible between the symbionts and the external environment (Fig. 1B,E). These observations support the assertion in Fujikura et al. that $M$. hadalis has intracellular symbionts unlike the symbioses in other thyasirid clams.

Secondary lysosomes containing the intermediate stages of bacterial digestion (Fig. 1D) indicated energy acquisition of the host from the symbionts (Fisher \& Childress 1992). Maorithyas hadalis has a short simple gut, which also suggests a nutritional reliance on its symbionts (Fujiwara unpubl. data).

Vacuoles at the apical ends of the bacteriocytes were sometimes open to the exterior ambient seawater, albeit rarely. At these sites, the host cell membrane was always clearly intact, indicating that these openings had not been caused by fixation artifacts. Similar openings have been reported in the symbiont-harboring gastropod species Alviniconcha hessleri and Ifremeria nautilei, and 2 deep-sea mussels, Bathymodiolus brevior and $B$. sp. affinis brevior from western Pacific hydrothermal vent sites (Endow \& Ohta 1989, Windoffer \& Giere 1997, Dubilier et al. 1998). Windoffer \& Giere suggested that these arrangements reflect a possible evolutionary pathway from extra- to intracellular symbioses. 

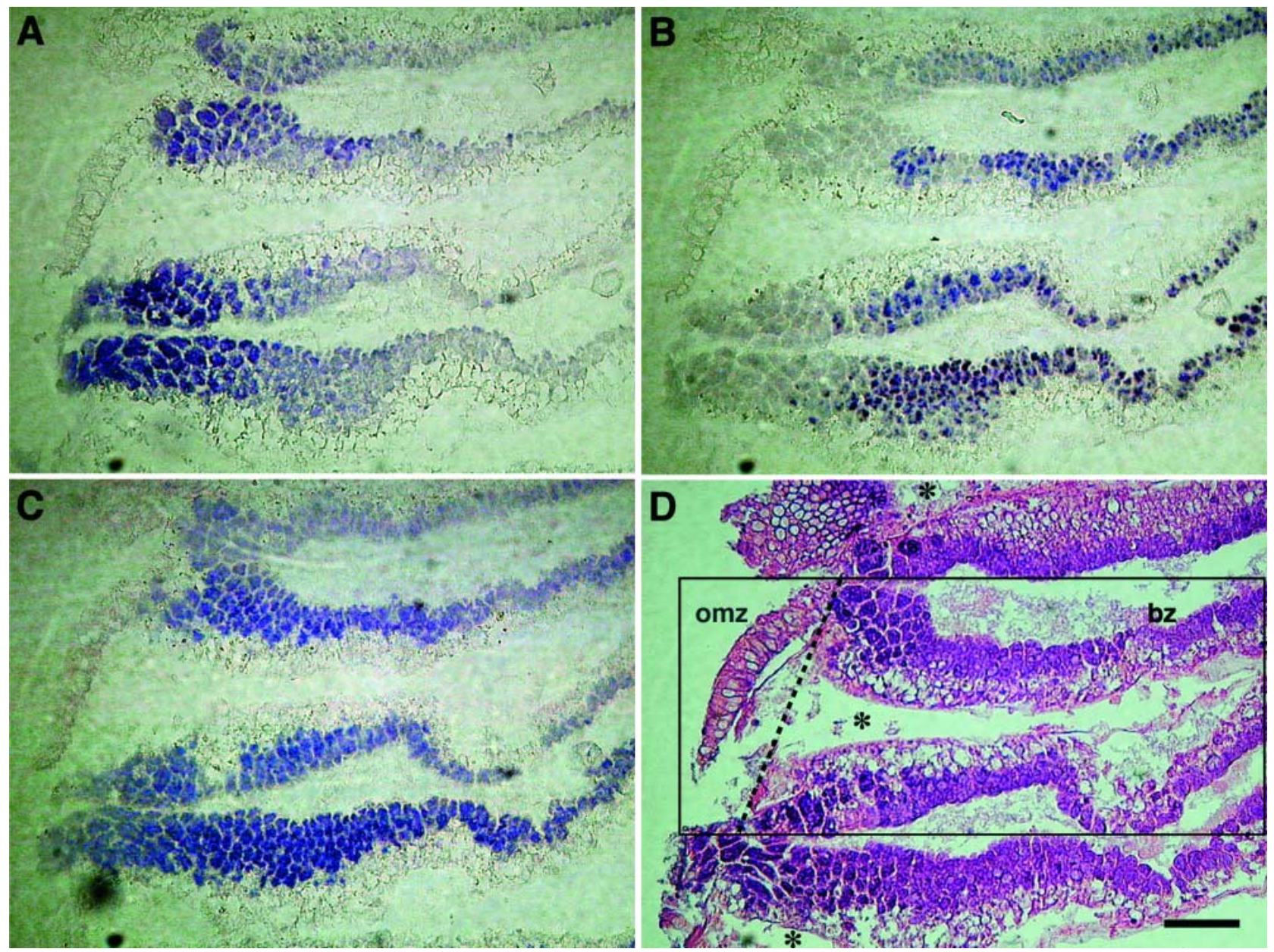

Fig. 4. Maorithyas hadalis. Photomicrographs of transverse sections of gill filaments. In situ hybridization of the following digoxigenin (DIG)-labeled oligonucleotides complementary to $16 \mathrm{~S}$ rDNA sequences are shown for the symbiont-specific (A) Probe I and (B) Probe II, and for (C) the universal eubacterial probe EUB338. (D) Hematoxylin-eosin (H\&E) staining; square frame indicates a section of a single gill filament that is divided (by dashed line) into an outermost zone (omz) and a bacteriocyte zone (bz); the outermost zone faces the mantle cavity (left side in all micrographs); $*$ : haemocoelic space (scale bar $=50 \mu \mathrm{m}$ )

The symbiosis in Maorithyas hadalis was distinct from other symbiotic associations in molluscs. Most molluscan hosts harbor a single phylotype of thioautotroph or methanotroph as a symbiont, although the coexistence of thioautotrophic and methanotrophic symbionts has been reported for deep-sea mussels (Distel et al. 1995, Pont et al. 1998, Robinson et al. 1998, Trask \& Van Dover 1999) and a hydrothermal vent gastropod (Gal'chenko et al. 1992). However, M. hadalis harbored 2 phylotypes of bacteria, and one of them was phylogenetically different from any other symbiotic or free-living bacteria.

Symbiont I was clearly a member of the $\gamma$ subdivision of Proteobacteria in this study based on molecular phylogenetic analyses and in situ hybridization. Although inferring metabolic capabilities from 16S rDNA phylogeny alone could be misleading, the thioautotrophic nature of Symbiont I was supported by its posi- tion in the bivalve symbiont clade, which was composed exclusively of symbionts already characterized as thioautotrophic (Distel et al. 1988, Peek et al. 1998, Fujiwara et al. 2000), and by the very close evolutionary relationship among these symbionts. In addition, Fujikura et al. (1999) gave supporting evidence that Maorithyas hadalis had thioautotrophic endosymbionts. Specifically, they noted high sulfur concentration in the gills, a hydrogen sulfide smell from the soft parts of the clam and the surrounding sediments, and the locally dark gray to black color of the sediments from their habitats, indicating an anoxic and high sulfide environment.

Phylogenetic analyses and in situ hybridization also demonstrated that Symbiont II belonged to the $\gamma$ subdivision of Proteobacteria. These bacteria represent a unique symbiotic lineage in marine invertebrates. The neighboring branches of Symbiont II consisted of the 
free-living chemoautotrophic bacteria (genera Thiomicrospira and Hydrogenovibrio). Thiomicrospira is a free-living thioautotrophic bacterial genus (Kuenen \& Robertson 1989), and H. marinus is a free-living hydrogen oxidizer (Nishihara et al. 1998). The physiological nature of Symbiont II remains unknown, since it was too distantly related to those bacteria to infer its metabolism from its phylogeny.

Both symbionts were phylogenetically different from the extracellular symbionts of Thyasira flexuosa, the only other thyasirid whose bacterial symbionts have been examined using $16 \mathrm{~S}$ rDNA sequencing. They were also different from the symbionts of other clams belonging to the same superfamily, Lucinacea. These phylogenetic differences between hosts and symbionts in the same host superfamily may result from the mode of symbiont transmission. The endosymbionts of Codakia orbicularis are environmentally transmitted to a new host generation after larval metamorphosis (Gros et al. 1996). Since Maorithyas hadalis belongs to the same superfamily of $C$. orbicularis, the same mode of symbiont transmission may occur.

Similarity analysis showed the specificity of Probe II, but that Probe I had some similarity to the homologous position of the 16S rDNA sequences of 2 Bathymodiolus species. However, our RFLP and DNA sequence analyses showed no deep-sea mussel symbiont sequences from the Maorithyas hadalis gills. Thus, it was not possible that Probe I had reacted with the 16S rDNA sequences of deep-sea mussel symbionts on the sections of $M$. hadalis gills. Although Probe II weakly hybridized with the $16 \mathrm{~S}$ rDNA sequence of Symbiont I, the hybridization patterns of Probes I and II were clearly different. Therefore, the contribution of any reaction of Probe II with Symbiont I was negligible.

Spatial partitioning between the 2 phylotypes of symbionts was a unique feature of this dual symbiosis in Maorithyas hadalis. Our in situ hybridization experiments showed the difference between the distribution patterns of the 2 symbiont types. Symbiont I was more concentrated near the surface of the gill than Symbiont II. Since no chemosynthetic endosymbionts have been cultured to date, it is difficult to explain the role of each symbiont for the host. One possible explanation for the spatial partitioning might be as an adaptation to a chemical gradient in the host gill tissue, such as oxygen, sulfide and carbon dioxide concentrations.

It should be noted that 2 morphological types of symbionts are known from 2 other deep-sea thyasirids (Southward 1986), but no phylogenetic analysis to date has shown the dual symbiosis described here. Fisher (1990) suggested that the presence of 2 distinct symbionts in a single thyasirid individual might be a reflection of the fact that these associations were not as selective as the more integrated intracellular lucinid associations. However, the symbiosis of Maorithyas hadalis is intracellular, and therefore presumably just as integrated.

Acknowledgements. We are very grateful to Professor Kensaku Tamaki for leading the cruise in the Japan Trench using the ROV 'Kaiko'. We thank Dr James C. Hunt for his useful suggestions and critical reading of this manuscript, Dr Ken Takai and Ms Hisako Hirayama for useful advice on the experiments, and Katsuyuki Uematsu for TEM observations. We also thank the operation team of the ROV 'Kaiko' and the captain and crew of the RV 'Kairei'.

\section{LITERATURE CITED}

Allen JA (1958) On the basic form and adaptations to habitat in the Lucinacea (Eulamellibranchia). Phil Trans R Soc Lond B Biol Sci 241:421-484

Altschul SF, Madden TL, Schäffer AA, Zhang J, Zhang Z, Miller W, Lipman DJ (1997) Gapped BLAST and PSIBLAST: a new generation of protein database search programs. Nucleic Acids Res 25:3389-3402

Amann RI, Binder BJ, Olson RJ, Chisholm SW, Devereux R, Stahl DA (1990) Combination of 16S rRNA-targeted oligonucleotide probes with flow cytometry for analyzing mixed microbial populations. Appl Environ Microbiol 56: 1919-1925

Benson DA, Karsch-Mizrachi I, Lipman DJ, Ostell J, Rapp BA, Wheeler DL (2000) GenBank. Nucleic Acids Res 28:15-18

Cary SC (1994) Vertical transmission of a chemoautotrophic symbiont in the protobranch bivalve, Solemya reidi. Mol Mar Biol Biotechnol 3:121-130

Di Meo CA, Wilbur AE, Holben WE, Feldman RA, Vrijenhoek RC, Cary SC (2000) Genetic variation among endosymbionts of widely distributed vestimentiferan tubeworms. Appl Environ Microbiol 66:651-658

Distel DL, Cavanaugh CM (1994) Independent phylogenetic origins of methanotrophic and chemoautotrophic bacterial endosymbioses in marine bivalves. J Bacteriol 176: 1932-1938

Distel DL, Wood AP (1992) Characterization of the gill symbiont of Thyasira flexuosa (Thyasiridae: Bivalvia) by use of polymerase chain reaction and 16S rRNA sequence analysis. J Bacteriol 174:6317-6320

Distel DL, Lane DJ, Olsen GJ, Giovannoni SJ, Pace B, Pace NR, Stahl DA, Felbeck H (1988) Sulfur-oxidizing bacterial endosymbionts: analysis of phylogeny and specificity by 16S rRNA sequences. J Bacteriol 170:2506-2510

Distel DL, Felbeck H, Cavanaugh CM (1994) Evidence for phylogenetic congruence among sulfur-oxidizing chemoautotrophic bacterial endosymbionts and their bivalve hosts. J Mol Evol 38:533-542

Distel DL, Lee HKW, Cavanaugh CM (1995) Intracellular coexistence of methano- and thioautotrophic bacteria in a hydrothermal vent mussel. Proc Natl Acad Sci USA 92: 9598-9602

Dubilier N, Giere O, Distel DL, Cavanaugh CM (1995) Characterization of chemoautotrophic bacterial symbionts in a gutless marine worm (Oligochaeta, Annelida) by phylogenetic 16S rRNA sequence analysis and in situ hybridization. Appl Environ Microbiol 61:2346-2350

Dubilier V, Windoffer R, Giere O (1998) Ultrastructure and stable carbon isotope composition of the hydrothermal vent mussels Bathymodiolus brevior and B. sp. affinis brevior 
from North Fiji Basin, western Pacific. Mar Ecol Prog Ser 165:187-193

Dubilier N, Amann R, Erséus C, Muyzer G, Park SY, Giere O, Cavanaugh CM (1999) Phylogenetic diversity of bacterial endosymbionts in the gutless marine oligochete Olavius loisae (Annelida). Mar Ecol Prog Ser 178:271-280

Durand P, Gros O (1996) Bacterial host specificity of Lucinacea endosymbionts: interspecific variation in 16S rRNA sequences. FEMS Microbiol Lett 140:193-198

Durand P, Gros O, Frenkiel L, Prieur D (1996) Phylogenetic characterization of sulfur-oxidizing bacterial endosymbionts in three tropical Lucinidae by 16S rDNA sequence analysis. Mol Mar Biol Biotechnol 5:37-42

Eisen JA, Smith SW, Cavanaugh CM (1992) Phylogenetic relationships of chemoautotrophic bacterial symbionts of Solemya velum Say (Mollusca: Bivalvia) determined by 16S rRNA gene sequence analysis. J Bacteriol 174: 3416-3421

Endow K, Ohta S (1989) The symbiotic relationship between bacteria and a mesogastropod snail, Alviniconcha hessleri, collected from hydrothermal vents of the Mariana Back-Arc Basin. Bull Jpn Soc Microb Ecol 3:73-82

Feldman RA, Black MB, Cary CS, Lutz RA, Vrijenhoek RC (1997) Molecular phylogenetics of bacterial endosymbionts and their vestimentiferan hosts. Mol Mar Biol Biotechnol 6:268-277

Fisher CR (1990) Chemoautotrophic and methanotrophic symbioses in marine invertebrates. Rev Aquat Sci 2: 399-436

Fisher CR, Childress JJ (1992) Organic carbon transfer from methanotrophic symbionts to the host hydrocarbon-seep mussel. Symbiosis 12:221-235

Fujikura K, Kojima S, Tamaki K, Maki Y, Hunt J, Okutani T (1999) The deepest chemosynthesis-based community yet discovered from the hadal zone, $7326 \mathrm{~m}$ deep, in the Japan Trench. Mar Ecol Prog Ser 190:17-26

Fujiwara Y, Takai K, Uematsu K, Tsuchida S, Hunt JC, Hashimoto J (2000) Phylogenetic characterization of endosymbionts in three hydrothermal vent mussels: influence on host distributions. Mar Ecol Prog Ser 208:147-155

Gal'chenko VF, Pimenov NV, Lein AY, Galkin SV, Miller YM, Ivanov MV (1992) Mixotrophic type of feeding of Olgaconcha tufari Beck (Gastropoda: Prosobranchia) from the active hydrothermal field of the Manus Basin (Bismarck Sea). Dokl Biol Sci 323:125-129

Gros O, Darrasse A, Durand P, Frenkiel L, Mouëza M (1996) Environmental transmission of a sulfur-oxidizing bacterial gill endosymbiont in the tropical lucinid bivalve Codakia orbicularis. Appl Environ Microbiol 62:2324-2330

Kato C, Li L, Tamaoka J, Horikoshi K (1997) Molecular analy-

Editorial responsibility: Otto Kinne (Editor),

Oldendorf/Luhe, Germany ses of the sediment of the 11000-m deep Mariana Trench. Extremophiles 1:117-123

Kauffman EG (1967) Cretaceous Thyasira from the western interior of North America. Smithson Misc Collec 152:1-159

Kuenen JG, Robertson LA (1989) Genus Thiomicrospira. In: Staley JT, Bryant MP, Pfenning N, Holt JG (eds) Bergey's manual of systematic bacteriology. Williams \& Wilkins, Baltimore, p 1858-1861

Lane DJ (1991) 16S/23S sequencing. In: Stackebrandt E, Goodfellow M (eds) Nucleic acid techniques in bacterial systematics. John Wiley \& Sons, Chichester, p 115-175

Nishihara H, Yaguchi T, Chung SY, Suzuki KI, Yanagi M, Yamasato K, Kodama T, Igarashi Y (1998) Phylogenetic position of an obligately chemoautotrophic, marine hydrogen-oxidizing bacterium, Hydrogenovibrio marinus, on the basis of 16S rRNA gene sequences and two form I RuBisCO gene sequences. Arch Microbiol 169:364-368

Okutani T, Fujikura K, Kojima S (1999) Two new hadal bivalves of the family Thyasiridae from the plate convergent area of the Japan Trench. Venus Jpn J Malacol 58:49-54

Peek AS, Feldman RA, Lutz RA, Vrijenhoek RC (1998) Cospeciation of chemoautotrophic bacteria and deep sea clams. Proc Natl Acad Sci USA 95:9962-9966

Pond DW, Bell MV, Dixon DR, Fallick AE, Segonzac M, Sargent JR (1998) Stable-carbon-isotope composition of fatty acids in hydrothermal vent mussels containing methanotrophic and thiotrophic bacterial endosymbionts. Appl Environ Microbiol 64:370-375

Robinson JJ, Polz MF, Fiala-Médioni A, Cavanaugh CM (1998) Physiological and immunological evidence for two distinct $\mathrm{C}_{1}$-utilizing pathways in Bathymodiolus puteoserpentis (Bivalvia: Mytilidae), a dual endosymbiotic mussel from the Mid-Atlantic Ridge. Mar Biol 132:625-633

Southward EC (1986) Gill symbionts in thyasirids and other bivalve molluscs. J Mar Biol Assoc UK 66:889-914

Takai K, Sako Y (1999) A molecular view of archaeal diversity in marine and terrestrial hot water environments. FEMS Microbiol Ecol 28:177-188

Thompson JD, Gibson TJ, Plewniak F, Jeanmougin F, Higgins DG (1997) The CLUSTAL_X windows interface: flexible strategies for multiple sequence alignment aided by quality analysis tools. Nucleic Acids Res 25:4876-4882

Trask JL, Van Dover CL (1999) Site-specific and ontogenetic variations in nutrition of mussels (Bathymodiolus sp.) from the Lucky Strike hydrothermal vent field, Mid-Atlantic Ridge. Limnol Oceanogr 44:334-343

Windoffer R, Giere O (1997) Symbiosis of the hydrothermal vent gastropod Ifremeria nautilei (Provannidae) with endobacteria - structural analyses and ecological considerations. Biol Bull 193:381-392

Submitted: May 18, 2000; Accepted: October 17, 2000

Proofs received from author(s): March 26, 2001 